УДК 172

DOI: 10.18101/1994-0866-2020-1-32-38

\title{
КОНЦЕПЦИИ ГОСУДАРСТВА В ФИЛОСОФСКИХ УЧЕНИЯХ ДРЕВНЕГО КИТАЯ И ИХ СОВРЕМЕННОЕ ЗНАЧЕНИЕ
}

\author{
(C) Бальчиндоржиева Оюна Баировна \\ доктор философских наук, доцент, \\ Бурятский государственный университет имени Доржи Банзарова \\ Россия, 670000, г. Улан-Удэ, ул. Смолина, 24а \\ E-mail: baoyu2008@yandex.ru
}

\begin{abstract}
В настоящей статье рассматриваются основные философские, политические и правовые учения китайской философии (отраженные в основных канонах конфуцианства, легизма, моизма, даосизма) о сущности государства, об управлении обществом, о социальном идеале, сформировавшиеся в древности и продолжающие оказывать свое влияние в современный период. Автор статьи проводит сравнительный анализ воззрений об идеальном правителе, идеальном государстве, эффективности тех или иных способов управления древних китайских мыслителей. Автор обосновывает идею о том, что данные концепции значимы и для современного китайского общества, находящегося в условиях трансформации. Также в статье делается попытка проследить взаимовлияние некоторых современных концептов (на примере концепта «китайская мечта») и традиционных для китайского общества идей об идеальном обществе и о наиболее эффективных способах государственного управлении.

Ключевые слова: конфуцианство; Мэн-цзы; Сюнь-цзы; моизм; легизм; китайская мечта; социальная философия; государство.
\end{abstract}

\section{Для цитирования}

О. Б. Бальчиндоржсиева. Концепции государства в философских учениях Древнего Китая и их современное значение // Вестник Бурятского государственного университета. Философия. 2020. Вып. 1. С. 32-38.

Одной из важнейших проблем древней китайской философии была проблема роли и значения государства в жизни людей. Вопросы о происхождении государства, об источниках государственной власти, о способах управления обществом решались практически во всех школах китайской философии. Рассмотрим их подробнее.

\section{Моизм}

С точки зрения моизма государство находится в своем наилучшем или идеальном состоянии, когда каждый гражданин проявляет всеобщую любовь и заботу (цзянь ай 兼愛). В учении моистов долг правителя рассматривается как обязанность, вытекающая из универсальных и беспристрастных моральных принципов.

В трактате «Мо-цзы» в разделе «Согласие с господином» развивается идея о том, что воля народа и воля Неба - два начала авторитета правителя. Отвечая на вопрос, почему возникла необходимость создания государства, Мо-цзы пишет, 
О. Б. Бальчиндоржсиева. Концепции государства в философских учениях Древнего Китая и их современное значение

что в те далекие времена «у каждого было свое мерило правильного и неправильного. Где был один человек, было одно мерило. Где было два человека, было два мерила, где было десять человек, было десять мерил. Чем больше было людей, тем больше было мерил. Каждый считал себя правым, а других - неправыми. Поднебесная пребывала в великом хаосе, и люди были подобны зверям и птицам. Они поняли, что все беспорядки в Поднебесной оттого, что у них нет правителя. Поэтому они выбрали самого добродетельного и самого способного во всей Поднебесной и сделали его Сыном Неба» [1, с. 79-80]. Таким образом, люди, предпочитая хаосу порядок, по своей воле выбирают правителя.

В чем же заключается воля Неба? Об этом речь идет в следующей главе. «В древности Небо и духи установили государство и города и возвели правителей не для того, чтобы сделать их ранги высокими, а вознаграждения - щедрыми... Это было сделано для того, чтобы дать людям благо и избавить их от напастей, чтобы обогатить бедных и умножить немногих, чтобы превратить опасность в спокойствие, а хаос — в порядок» («Мо-цзы», гл. 12) [1, с. 80].

Роль правителя состоит в том, чтобы выработать «единые мерила» для народа. Определяя меры «правильного» и «неправильного», правитель должен понимать, что правильное - это следование «взаимной всеобщности», а неправильное - следование «взаимному исключению» [1, с. 81]. Тот, кто придерживается принципа исключения, говорит: «Смешно заботиться о друзьях так же, как и о себе, и помогать их родителям так же, как своим». Поэтому такой человек не делает слишком много для друзей. Но тот, кто придерживается принципа всеобщности, говорит: «Я должен заботиться о друзьях точно так же, как и о себе, и об их родителях так же, как и о своих». Поэтому он делает для друзей все, что может [1, с. 74].

Сравнивая концепцию государства моизма с легистской и конфуцианской доктринами, отметим, что общим является то, что во всех вышеназванных доктринах признается необходимость подчинения авторитету правителя (централизованной власти) и иерархическая структура общества. Однако есть и отличия, например в моизме не ставится вопрос о злой или доброй природе человека. Однако можно сказать, что в моизме акцент делается на разумности людей, благодаря которой люди могут выбрать между хаосом и порядком. На первый взгляд, принцип «всеобщности» или «всеобщей любви» выглядит как утопия, однако при более внимательном отношении мы видим, что он имеет утилитаристское обоснование и приближен к принципу «разумного эгоизма». Тот, кто имеет «чуткие уши и глаза», поймет, что все бедствия происходят по причине ненависти и причинения вреда другим, и наоборот, благо возникает тогда, когда «государства и города не нападают и не захватывают друг друга, когда семьи и люди не разоряют и не причиняют вред друг другу» («Мо-цзы», гл. 16) [1, с. 76]. В этом и есть «взаимная выгода» - второй принцип моизма.

\section{Конфуцианство. Мэн-цзы и Сюнь-цзы}

Учитель Кун соотносит процесс управления с нормами «дэ» — добродетель, «жэнь» — человеколюбие, «и» — долг, «ли» — ритуал. Для этого нужно прове- 
сти процедуру выпрямления (чжэн): «Правление - это выпрямление». Л. С. Переломов при переводе «Луньюя» для передачи понятия «выпрямление» использует термин «совершенствование»: «Если человек способен сам исправить себя, то разве будут ему трудны дела государства? Если же не способен сам исправить себя, то как он сможет исправлять других?» [4, с. 390]. «Выпрямление» начинается с «выпрямления имен» (чжэн мин): «Если имена неправильны, то слова не имеют под собой оснований. Если слова не имеют под собой оснований, то дела не могут осуществляться. Если дела не могут осуществляться, то ритуал и музыка не процветают. Если ритуал и музыка не процветают, наказания не применяются надлежащим образом. Если наказания не применяются надлежащим образом, народ не знает, как себя вести. Поэтому благородный муж, давая имена, должен произносить их правильно, а то, что произносит, правильно осуществлять. В словах благородного мужа не должно быть ничего неправильного» [4, c. 317]. Государственное управление строится на ритуале, который охватывает все уровни сверху донизу (правитель - чиновники - народ).

Последователей же конфуцианства Мэн-цзы и Сюнь-цзы более всего занимает проблема человеческой природы. Сюнь-цзы выдвигает положение о том, что «Человек по своей природе зол, его добродетельность порождается [практической] деятельностью» («Сюнь-цзы», гл. 23) [3, с. 200]. Погоня за выгодой, удовлетворение потребностей движет людьми. «Люди любят и ненавидят одни и те же вещи, но желающих много, а вещей мало. Поскольку вещей мало, это неизбежно приводит к соперничеству» («Сюнь-цзы», гл. 10) [3, с. 160]. Раздоры и беспорядок также не удовлетворяют Сюнь-цзы, как и Мо-цзы. Разум подсказывает нам, что необходимость совместного бытия многих людей принуждает к разумному сотрудничеству и взаимной поддержке. Для этого необходимо установить регулирующее начало, правила поведения «ли» (ритуалы), цель которых - ограничить желания людей. Ли (ритуалы) в концепции Сюнь-цзы тесно связаны с нравственностью. «Тот, кто поступает в соответствии с ли, поступает нравственно. Тот, кто поступает в противоречии с ли, поступает безнравственно» $[1$, c. 171$]$.

Таким образом, общим местом для моизма и концепции Сюнь-цзы является утилитаристское понимание стремления человека к добру. Мэн-цзы же обходит стороной данные аргументы. Он полагает, что природа человека добра, и для человека естественно стремление к добру. В качестве одного из основных способов управления Мэн-цзы выдвигает требование «ценить народ». Народом надо управлять «великодушно», что народ сначала надо обогатить и только потом учить. Главная забота правителя - постоянная забота о материальном благополучии людей, ведь чтобы получить Поднебесную, вначале нужно завоевать «сердце народа». Отметим, что Мэн-цзы не являлся сторонником насильственных методов государственного управления.

Развивая конфуцианское учение о способах государственного управления, Сюнь-цзы приходит к идее о сочетании ли (ритуалы) и фа (законы). «Великий долг в управлении делами [государства] состоит в следующем: того, кто прихо- 
О. Б. Бальчиндоржсиева. Концепции государства в философских учениях Древнего Китая и их современное значение

дит с добрыми намерениями, следует встречать в соответствии с нормами ритуала; того же, кто приходит не с добрыми намерениями, следует встречать законами об уголовных наказаниях» («Сюнь-цзы», гл. 9) [3, с. 150].

Дальнейшие рассуждения Сюнь-цзы также обосновывают тезис о необходимости разумного сочетания наказаний и великодушного правления, на основе мира и справедливости. Его идеи во многом являются синтезом идей традиционных китайских философских школ.

\section{Даосизм}

Один из самых ранних даосских текстов «Тайпин цзин» (Канон великого равновесия) обосновывает идеал гармоничного общества, управляемого гармоничной личностью. В данном трактате ставится вопрос об эффективности властных институтов, которая зависит о следования естественным явлениям, диагностирующим настроения в обществе [2, с. 115]. Сам термин «Тайпин» достаточно полисемантичен и может иметь значения не только великого равновесия, но и великого покоя, великого умиротворения, великого благоденствия. Данный идеал настаивает не на построении иерархического государства, но на единстве и сотрудничестве различных слоев общества. К важнейшему уроку из исследования концепции государственного управления в даосизме можно отнести понимание государства как должного социального взаимодействия, обретения единства с Дао. Можно говорить и о противостоянии с учением Конфуция: «необходимо... уничтожить в Поднебесной все правила совершенномудрых, и тогда можно будет начать с народом рассуждать [о дао]...» («Чжуанцзы», гл. 10) [3, с. 267]. Также в более раннем источнике «Дао дэ цзин» говорится: «Когда Дао утрачено, появляется Дэ. Когда Дэ утрачено, появляется гуманность. Когда гуманность утрачена, появляется справедливость. Когда справедливость утрачена, появляется ритуал. Ритуал - это вырождение верности и искренности и начало беспорядка в Поднебесной» (гл. 38) [1, с. 124].

\section{Легизм}

Легизм достаточно известно в качестве концепции деспотизма. В рамках данной концепции обосновывается необходимость сильной, централизованной власти. Анализируя учения представителей легизма, выделим несколько важных аспектов в понимании ими природы «法治» (концепции управления на основе закона). Во-первых, обоснование необходимости порядка в государстве посредством единых и равных для всех законов. Наличие единых законов рассматривалось как необходимое условие сильного и процветающего государства. Вовторых, ограничение произвола чиновников и наместников. Из сферы действия закона исключался только правитель, чиновников, так же как и всех, ожидало строгое наказание за нарушение закона.

По мнению Хань Фэй-цзы, правитель должен совершенствовать искусство управления (шу). «Технология» власти может быть поставлена в один ряд с понятием фа (закон). Для сохранения монополии на политическую власть правитель должен следить за тем, чтобы крупные чиновники не могли завладеть слишком большим политическим «авторитетом». Чиновники должны выполнять свои 
обязанности эффективно, контролировать исполнение законов в соответствии со строго определенными стандартами, правитель же контролирует деятельность чиновников. Таким образом, привилегированное положение занимает только правитель, для которого закон лишь средство. Такое инструменталистское отношение к законам сохранялось в Китае на протяжении длительного периода.

Воззрения легистов на философию истории, в отличие от других философских школ, являлись не консервативными, а скорее эволюционистскими, по крайней мере, они отмечали изменчивость исторических условий. Действительно, в процессе развития общества изменяются материальные условия жизни, вместе с ними - законы и ритуалы.

В целом учение легизма наибольшие противоречия имеет с учением даосизма. С точки зрения даосизма правитель не должен совершенствоваться в искусстве правления, наоборот, он должен постигать непознаваемое Дао, следовать естественному ходу вещей, стремиться не к действиям, а к покою. Государству не нужно множество законов и правил, наоборот, «чем больше в Поднебесной ограничений и запретов, тем беднее народ... Чем больше издавать законов, тем больше будет воров и разбойников» («Дао дэ цзин», гл. 27) [1, с. 125]. Хотя в последующем развитии в китайской философии сложилось определенное гармоничное соотношение двух основных идей: управления государством на основе нравственности (дэ) (кит. 以德治国《и дэ чжиго») и управления государством посредством законов (кит. 以法治国 «и фа чжиго»).

В последующие периоды развития философии в Китае имела место диффузия идей, и конфуцианство во многом восприняло идеи других философских учений. Впоследствии, как нам известно, оно было возведено в ранг государственной идеологии.

В целом, подводя итоги, отметим, что традиционные для китайской философии представления о государстве основываются на таких положениях, как:

1) народ - это основа, в основе политики правителя должна быть забота о народе;

2) наличие сильной верховной власти, иерархичная структура общества;

3) обеспечение единых правил, норм поведения;

4) ограничение произвола правителя, чиновников;

5) выполнение долга.

В предыдущих своих статьях мы не раз отмечали важность традиции в современном китайском мировоззрении и то, что нынешнее руководство КНР также использует традиционные воззрения при определении долгосрочных перспектив развития страны. Как совершенно справедливо утверждает Н. А. Абрамова, «разработанность проблем управления государством и обществом разными философскими школами сформировало в китайском обществе механизм обращения к древности как способа легитимации актов власти, который со временем стал основным содержанием традиционной политической культуры, оказывая сильное воздействие на сознание и поведение субъектов и объектов китайской политики. Данный феномен наблюдается и в современной общественно-политической 
О. Б. Бальчиндоржсиева. Концепции государства в философских учениях Древнего Китая и их современное значение

жизни КНР» [5, с. 40]. Для подтверждения этой мысли достаточно вспомнить о выдвигаемой в последние годы концепции «китайской мечты». Что такое китайская мечта? Что составляет основу национального возрождения Китая? На этот вопрос пытаются ответить зарубежные и российские исследователи. Ю. М. Тавровский отмечает, что сердцевина китайской мечты - патриотизм [6]. А. Е. Лукьянов полагает, что китайская мечта пропитана духом конфуцианства, восходит к древнейшим символам сяокан-датун, сопровождается и усиливается даосскими идеалами [7, с. 58]. Зачастую китайские лидеры прямо или косвенно цитируют древних китайских философов в своих выступлениях.

Конечно, концепт «китайской мечты» связан и с предыдущими элементами теории «социализма с китайской спецификой»: с идеями Мао Цзэдуна, теорией Дэн Сяопина, идеями тройного представительства Цзян Цзэминя, научной программой развития Ху Цзиньтао, являя собой некий курс на обновление, что совершенно справедливо обозначил И. И. Грузинин [7, с. 354]. Он отмечает и то, что «мечта» отражает запрос на сближение партии и народа, агрегирование и артикуляцию потребностей народа, что в некоторой степени наводит на проведение параллелей с пониманием функции государства в учении даосизма.

Идея национального возрождения и воспитания патриотизма в китайском обществе как стратегическая задача продвигается достаточно планомерно длительный период времени. Так, на рубеже XX-XXI вв. коммунистической партией была выдвинута установка неуклонно возвышать и внедрять национальный дух (квинтэссенцию всей китайской культуры, в том числе традиционной) как основу развития нации. Данная установка влияет на все уровни образования, охватывает многие виды искусства, т. е. в целом пронизывает сферы духовной жизни общества. Ее ценности включают трудолюбие, самосовершенствование, прагматизм, единение, уважение к традиции и почитание «дэ».

В настоящее время в Китае происходит постоянный поиск форм консолидации китайского общества, а также более мягких, гибких способов руководства, с обращением к традиционным ценностям и нормам. При наличии острых социальных проблем, противоречий, тем не менее выдвигаются такие главные направления и цели развития современного китайского общества, как совершенствование законодательства, повышение нравственных качеств личности, достижение гармоничных социальных отношений и отношения «общество природа».

Литература

1. Фэн Ю-лань. Краткая история китайской философии. URL: https://www.abirus.ru/user/files/Ebooks/Fengyoulan.pdf (дата обращения: 03.02.2020).

2. Мартынов Д. Е. Даосская утопия Тайпин: политические и этические аспекты // Ученые записки казанского государственного университета. Гуманитарные науки. 2006. Т. 148, кн. 4. С. 106-118.

3. Древнекитайская философия / сост. Ян Хин-шун. М., 1972. Т. 2. 382 с.

4. Переломов Л. С. Конфуций: Луньюй. М.: Восточная литература, 2001. 264 с. ISBN 5-02-018024-6 
5. Абрамова Н. А. Политическая культура Китая: традиции и современность: автореф. дис. ... д-ра филос. наук. Улан-Удэ: Изд-во Бурят. гос. ун-та, 2003. 44 с.

6. Тавровский Ю. Китайская мечта итоги «первой пятилетки» Си Цзиньпина. URL: http://zavtra.ru/blogs/kitajskaya_mechta (дата обращения 04.02.2020).

7. Лукьянов А. Е. Философские прообразы «китайской мечты» // Вестник РУДН. Сер. Философия. 2015. № 4. С. 50-59.

8. Грузинин И. И. Позиции идеи «китайская мечта» в идеологической сфере КПК после 2017 г. // Социально-гуманитарные знания. 2019. № 4. С. 350-355.

\section{CONCEPTS OF THE STATE IN A SYSTEM OF ANCIENT CHINA PHILOSOPHY AND ITS CONTEMPORARY RELEVANCE}

Oyuna B. Balchindorzhieva

Dr. Sci. (Philos.), A/Prof.,

Dorzhi Banzarov Buryat State University

24a Smolina St., Ulan-Ude 670000, Russia

E-mail: baoyu2008@yandex.ru

The article discusses the main philosophical, political and legal doctrines of Chinese philosophy (reflected in the kanons of Confucianism, Legalism, Mohism, Taoism) about the essence of the state, ways of governing society, a social ideal. They were created in antiquity and continue to exert their influence in the modern period. We have carried out a comparative analysis of the views of ancient Chinese thinkers on an ideal ruler, an ideal state, the effectiveness of various methods of government. It has been substantiated that these concepts are significant for modern Chinese society, which is in a transformational period today. We have also made an attempt to trace the interplay of some modern concepts (using the concept of Chinese dream as an example) and traditional for Chinese society ideas about an ideal society and the most effective ways of governance.

Keywords: Confucianism; Mencius; Xunzi; Mohism; Legalism; Chinese dream; social philosophy; the state. 